\title{
Electrochemical Disinfection of Bacteria-Laden Water Using Antimony-Doped Tin-Tungsten- Oxide Electrodes
}

\author{
Resubmitted to: \\ Water Research \\ August 31, 2017
}

SALOUMEH GHASEMIAN, BAHAREH ASADISHAD, SASHA OMANOVIC, and NATHALIE TUFENKJI*

Department of Chemical Engineering, McGill University, Montreal, Quebec H3A 0C5, Canada

*Corresponding Author. Phone: (514) 398-2999; Fax: (514) 398-6678; E-mail: nathalie.tufenkji@mcgill.ca 


\begin{abstract}
Electrochemical disinfection has been shown to be an efficient method with a shortrequired contact time for treatment of drinking water supplies, industrial raw water supplies, liquid foodstuffs, and wastewater effluents. In the present work, the electrochemical disinfection of saline water contaminated with bacteria was investigated in chloride-containing solutions using Sb-doped $\mathrm{Sn}_{80 \%}-\mathrm{W}_{20 \%}$-oxide anodes. The influence of current density, bacterial load, initial chloride concentration, solution $\mathrm{pH}$, and the type of bacteria (E. coli D21, E. coli O157:H7, and E. faecalis) on disinfection efficacy was systematically examined. The impact of natural organic matter and a hydroxyl radical scavenger on the disinfection process was also examined. The electrochemical system was highly effective in bacterial inactivation for a 0.1 $\mathrm{M} \mathrm{NaCl}$ solution contaminated with $\sim 10^{7} \mathrm{CFU} / \mathrm{mL}$ bacteria by applying a current density $\geq$ $1 \mathrm{~mA} / \mathrm{cm}^{2} .100 \%$ inactivation of $E$. coli D21 was achieved with a contact time of less than 60 $s$ and power consumption of $48 \mathrm{Wh} / \mathrm{m}^{3}$, by applying a current density of $6 \mathrm{~mA} / \mathrm{cm}^{2}$ in a 0.1 $\mathrm{M} \mathrm{NaCl}$ solution. Reactive chlorine species as well as reactive oxygen species (e.g. hydroxyl radicals) generated in situ during the electrochemical process were determined to be responsible for inactivation of bacteria.
\end{abstract}

Keywords: Water disinfection, Electrochemical treatment, Chlorine, Bacteria, Tin, Tungsten 


\section{Introduction}

The elimination of pathogenic microorganisms, suspended or as attached biofilms, is a primary step in the treatment of water from many different sources, such as raw water supply (Trussell 1998), ballast water (Nanayakkara 2010), drinking water reservoirs and water distribution systems (Flemming 2002), process wash water in food processing plants (López-Gálvez et al. 2012), brackish or industrial briny waters for use in food industry, swimming pools and drinking water (Feng et al. 2004, Martínez-Huitle and Brillas 2008), amongst many others. This is usually carried out by adding chemicals such as chlorine, chlorine dioxide and ozone (Harper et al. 2001, Rahmawati et al. 2010). The most common method, chlorination, is associated with some problems such as transport and storage of chlorine (Kraft et al. 1999, Rajeshwar and Ibanez 1997), generation of hazardous byproducts such as trihalomethanes (THMs), haloacetic acids (HAAs), and Nnitrosodimethylamine (NDMA) (A. Lawton and K. J. Robertson 1999, Gusmão et al. 2010, Mitch et al. 2003), and the resistance of some pathogens including pathogenic Escherichia coli (E. coli) and Campylobacter jejuni bacteria, enteric viruses such as rotavirus and calicivirus, and the parasites Cryptosporidium and Giardia lamblia (Gusmão et al. 2010, Szewzyk et al. 2000).

Electrochemical (EC) disinfection has gained attention as a potential alternative to conventional chlorination (Jeong et al. 2007, López-Gálvez et al. 2012) due to its environmental compatibility, easy installation and operation, and effectiveness for inactivation of a wide variety of microorganisms from bacteria to viruses and algae under mild pressures and temperature (Diao et al. 2004, Drees et al. 2003, Long et al. 2015, Mascia et al. 2013). It has been demonstrated that electrochemical technology can provide 
high disinfection efficiency for drinking water (Matsunaga et al. 1992), raw water supply (Patermarakis and Fountoukidis 1990), liquid foodstuff (Grahl and Märkl 1996), and industrial and domestic wastewater effluents (Anglada et al. 2009, Schmalz et al. 2009). The practice of cleaning water by passing an electric current had been reported as early as the nineteenth century; however, only recently has this technology come into long-term practical use (Kraft 2008).

Electrochemical water treatment is a green and powerful technology with a twostage mechanism of action: (1) direct oxidation at the electrode surface, which is characterized by the instantaneous killing of microbial cells (Jeong et al. 2007), and (2) indirect oxidation in the bulk solution by disinfecting species produced from water oxidation, such as hydroxyl radical $\left({ }^{\bullet} \mathrm{OH}\right)$, atomic oxygen $\left({ }^{\bullet} \mathrm{O}\right)$, hydrogen peroxide $\left(\mathrm{H}_{2} \mathrm{O}_{2}\right)$, and ozone $\left(\mathrm{O}_{3}\right)$ (Eqs. (1-5)) (Liang et al. 2005, Martínez-Huitle and Brillas 2008, Panizza and Cerisola 2005) classified as reactive oxygen species (ROS), or by oxidants produced from the substances dissolved in the water, e. g., chloride is oxidized to free chlorine, according to Eq. (6) (Anglada et al. 2009, Kraft 2008). Dissolved chlorine is subsequently hydrolyzed to hypochlorous acid/hypochlorite ion and hydrochloric acid, in main side reactions of anodic production of chlorine, as given in Eqs. (7) and (8). In water treatment, the overall concentration of dissolved chlorine after the chlorination process is termed active chlorine, and is given by the summation of three species: free chlorine $\left(\mathrm{Cl}_{2}\right)$, hypochlorous acid $(\mathrm{HClO})$ and hypochlorite ion $\left(\mathrm{ClO}^{-}\right)$. The mass distribution of these three main reactive chlorine species (RCS) depends on the $\mathrm{pH}$ of the medium (Bergmann and Koparal 2005).

$$
\mathrm{H}_{2} \mathrm{O} \rightarrow \mathrm{HO}^{\bullet}+\mathrm{H}^{+}+e^{-}
$$




$$
\begin{aligned}
& \mathrm{HO}^{\bullet} \rightarrow \mathrm{O}^{\bullet}+\mathrm{H}^{+}+\mathrm{e}^{-} \\
& 2 \mathrm{O}^{\bullet} \rightarrow \mathrm{O}_{2} \\
& 2 \mathrm{HO}^{\bullet} \rightarrow \mathrm{H}_{2} \mathrm{O}_{2} \\
& \mathrm{O}_{2}+\mathrm{O}^{\bullet} \rightarrow \mathrm{O}_{3} \\
& 2 \mathrm{Cl}^{-} \rightarrow \mathrm{Cl}_{2}+2 e^{-} \\
& \mathrm{Cl}_{2}+\mathrm{H}_{2} \mathrm{O} \rightarrow \mathrm{Cl}^{-}+\mathrm{HClO}+\mathrm{H}^{+} \\
& \mathrm{HClO} \rightarrow \mathrm{ClO}^{-}+\mathrm{H}^{+}
\end{aligned}
$$

Other advantages of electrochemical disinfection are on-site generation of disinfectants with controllable dose (Jeong et al. 2007) and relatively low energy requirement that allows the use of green energy sources such as solar cells or fuel cells (Drogui et al. 2001, Ghernaout et al. 2008). Overall, the high efficacy of electrochemical disinfection is attributed to the synergistic effects of direct oxidation on the electrode surface (Grahl and Märkl 1996, Matsunaga et al. 2000), generation of the reactive intermediate species such as ROS or RCS with strong bactericidal activity (Diao et al. 2004, Feng et al. 2004, Liang et al. 2005), and/or the electric field effect (Butterfield et al. 1997, Grahl and Märkl 1996).

The selection of an appropriate anode material is a key factor in electrocatalytic processes, as it influences not only the efficiency of the process, but also the electrode selectivity (Feng et al. 2016). Common anode materials used in studies of electrochemical water disinfection are titanium with active coatings based on metal oxides, which are known as Dimensionally Stable Anodes (DSA ${ }^{\circledR}$ s) (Gusmão et al. 2010), platinum (Jeong et al. 2007) and boron-doped diamond (BDD) electrodes (Lacasa et al. 2013, Long et al. 2015). DSA ${ }^{\circledR}$ type electrode materials include $\mathrm{IrO}_{2}-\mathrm{RuO}_{2}$ (Bergmann and Koparal 2005), 
$\mathrm{TiO}_{2}-\mathrm{RuO}_{2}$ (Gusmão et al. 2010), $\mathrm{SnO}_{2}$ (Watts et al. 2008), and $\mathrm{IrO}_{2}-\mathrm{Sb}_{2} \mathrm{O}_{5}-\mathrm{SnO}_{2}$ (Fang et al. 2006). These electrodes have shown higher efficiencies in the production of free chlorine compared to Pt and diamond electrodes, which is of primary importance in environmental applications of electrochemical technology in the presence of chloride salts (Bergmann et al. 2008, Kraft 2008). In addition, diamond electrodes may further oxidize hypochlorite to chlorate and perchlorate (Palmas et al. 2007) which are permissible in potable water only at very low concentrations (Kraft 2008). Therefore, DSA ${ }^{\circledR}$ type electrodes are more applicable for the electrochemical disinfection of water due to their higher efficiency in the production of oxidizing species.

The mechanism of electrochemical microbial inactivation is not completely understood. Fundamentally, the vital physiological functions of bacteria are based on the cell membrane, cytoplasm, and nucleic acids (DNA and RNA). Thus, damages to any of these subcellular constituents of bacteria could potentially lead to the inactivation of bacteria. Diao et al. (Diao et al. 2004) observed leakage of substantial intracellular materials from $E$. coli cells after electrochemical treatment by DSA ${ }^{\Theta_{S}}$ under scanning electron microscope. In another study, Jeong et al. (Jeong et al. 2006) observed changes in the inner content and cell walls of $E$. coli as a result of BDD disinfection. The work of Tanaka et al. (Tanaka et al. 2013) revealed lipid peroxidation in the cell membranes of electrochemically disinfected bacteria in seawater using a Pt anode. Long et al. (Long et al. 2015) investigated the subcellular mechanisms of $E$. coli inactivation during BDD electrochemical disinfection in three electrolytes: in chloride solution, E. coli inactivation was attributed to damage to the intracellular enzymatic systems; in sulfate solution, the elimination of certain essential membrane proteins such as $\mathrm{K}^{+}$ion transport systems mainly 
induced cell inactivation; and in phosphate solution, mineralization of their organic intracellular components was responsible for cell inactivation.

To the best of our knowledge, the performance of mixed metal oxide (MMO) electrodes consisting of antimony-tin-tungsten-oxides in electrochemical inactivation of microorganisms has not been investigated. In this context, the main objective of the present work was to examine the potential of electrochemical disinfection of saline water employing antimony-doped tin-tungsten-oxide electrode coatings ( $\mathrm{Sb}$-doped $\mathrm{Sn}_{80 \%}-\mathrm{W}_{20 \%}$ oxide) formed on a titanium substrate via a thermal deposition method. This electrode was selected as it was found to have high intrinsic electrocatalytic activity for oxidation of phenol red and the drug carbamazepine in our previous studies (Ghasemian et al. 2017, Ghasemian and Omanovic 2017). A non-pathogenic strain of E. coli was selected as a model bacterium, while pathogenic E. coli and Enterococcus faecalis (E. faecalis) were used to further validate the inactivation efficiency of the process. To examine the disinfection potential of the system, the electrochemical production of free chlorine as well as process parameters such as current density, bacterial cell density, $\mathrm{pH}$, and the presence of natural organic matter (NOM) and a radical scavenger were systematically investigated in chloride- and phosphate-containing solutions. Moreover, the energy requirement to reach a specific level of bacterial inactivation (3.5-log and 7.4-log reductions) at each current density was calculated. 


\section{Materials and Methods}

\subsection{Electrode Preparation}

Sb-doped $\mathrm{Sn}_{80 \%}-\mathrm{W}_{20 \%}$-oxide anode coatings were prepared on $50 \mathrm{~mm} \times 100 \mathrm{~mm} \times$ $2 \mathrm{~mm}$ flat titanium substrates employing a thermal deposition method. The titanium sheets were pretreated (polished, degreased and etched) before the deposition of the coatings. The metal salts used to prepare the coating precursor solution were $\mathrm{SnCl}_{2} .2 \mathrm{H}_{2} \mathrm{O}$ (ACS reagent, $\geq 98.0 \%$, Sigma Aldrich), $\mathrm{Na}_{2} \mathrm{WO}_{4} .2 \mathrm{H}_{2} \mathrm{O}$ (Certified ACS, $100.0 \%$, Fisher), and $\mathrm{SbCl}_{3}$ (ACS reagent, $\geq 99.0 \%$, Sigma Aldrich). All solutions were prepared using ultra-pure deionized water (resistivity: $18.2 \mathrm{M} \Omega \mathrm{cm}$ ). The metal-oxide coatings were formed by brushing the coating solution onto the pretreated side of Ti substrate (only one side of the Ti substrate was coated, while the other side was covered by an insulating tape), drying in oven at $100^{\circ} \mathrm{C}$ for $10 \mathrm{~min}$ to evaporate the solvent, and then baking in an air furnace at $500^{\circ} \mathrm{C}$ for $10 \mathrm{~min}$. This process was repeated ten times and after the last coating application, the electrodes were annealed at $500^{\circ} \mathrm{C}$ for 2 hours to complete the formation of metal oxides in the coating.

\subsection{Bacterial Strains and Growth Conditions}

The mutant of the E. coli K12 strain, D21, used in this study was obtained from the E. coli Genetic Stock Center at Yale University (CGSC \#5158). Results obtained with the model non-pathogenic organism E. coli D21 were compared with those obtained using two pathogenic strains; namely, E. coli O157:H7 ATCC 700927 (Gram-negative) and Enterococcus faecalis (E. faecalis) ATCC 29212 (Gram-positive). Inoculums were taken 
from pure cultures maintained at $-80^{\circ} \mathrm{C}$ in Luria Bertani (LB) Broth (Fisher, BP1427), spread onto LB agar plates, and incubated at $37^{\circ} \mathrm{C}$ overnight. For each experiment, a single colony from a fresh plate was used to inoculate $30 \mathrm{~mL}$ of sterile $\mathrm{LB}$ broth. Cultures were grown at $37^{\circ} \mathrm{C}$ for $18 \mathrm{~h}$ in a shaking incubator set at $180 \mathrm{rpm}$. After $18 \mathrm{~h}$ of incubation, corresponding to the stationary phase, cells were harvested by centrifugation at $5000 \mathrm{~g}$ for 10 min (Multifuge X3R, Thermo Heraeus) at $20^{\circ} \mathrm{C}$. The growth medium was decanted and the bacterial pellet was resuspended in $0.1 \mathrm{M}$ potassium phosphate buffer solution ( $\mathrm{pH} 7.1$ \pm 0.05 ) prepared from $\mathrm{KH}_{2} \mathrm{PO}_{4}$ salt (ACS Certified, Fisher) with $0.1 \mathrm{M} \mathrm{NaCl}$ (ACS Certified, Fisher), which was used as the background electrolyte in this work, unless otherwise stated. Centrifugation and resuspension were repeated one more time. The concentration of the cell suspension was determined by measuring its optical density at 600 nm using a UV-Vis spectrophotometer (Agilent 8453). To study the impact of initial bacterial load on disinfection, bacterial suspensions were prepared at $10^{5}$ and $10^{7}$ colony forming units $(\mathrm{CFU}) / \mathrm{mL}$.

\subsection{Electrochemical Reactor}

The electrochemical reactor consisted of a 900-mL beaker (Pyrex glass) with a Teflon lid and was placed in a water bath to keep the temperature constant at $25^{\circ} \mathrm{C}$ during the experiments. The working electrode was the prepared Sb-doped $\mathrm{Sn}_{80 \%}-\mathrm{W}_{20 \%}$-oxide film. An $80 \mathrm{~mm} \times 100 \mathrm{~mm} \times 2 \mathrm{~mm}$ curved stainless steel plate $(316 \mathrm{~L})$ served as the counter electrode. Both electrodes were placed vertically in the cell with $5.5 \mathrm{~cm}$ distance between them. Saturated calomel electrode (SCE) was used as the reference. The electrodes were connected to a power source providing constant current during experiments. The reactor 
medium was prepared using the bacterial inoculum diluted in the electrolyte $(0.1 \mathrm{M}$ potassium phosphate buffer with $0.1 \mathrm{M} \mathrm{NaCl}$ ), yielding a 550-mL bacterial suspension with initial concentration of $\sim 10^{7} \mathrm{CFU} / \mathrm{mL}$. The electrolyte and all the solutions used in this work were sterilized using $0.45 \mu \mathrm{m}$ pore filters (Corning 430625). The temperature of the electrolyte was monitored using a thermometer. Filtered air was bubbled into the solution during the experiments to provide mixing.

\subsection{Disinfection Experiments}

The coated electrode was sonicated in deionized water for 20 min before experiments to remove residual contamination from the surface of the electrode. The reactor was operated in a three-electrode mode and potentials were noted relative to SCE. The disinfection of bacterial suspension was carried out at constant current densities of 0.2, $1,2,4,6$ and $10 \mathrm{~mA} / \mathrm{cm}^{2}$ with $10^{7} \mathrm{CFU} / \mathrm{mL}$ initial bacterial concentration. The voltage and temperature at each sampling time were recorded. Before starting each electrochemical experiment, a $100 \mu \mathrm{L}$ sample was taken from the reactor with a sterile pipette to determine the initial concentration of bacteria. Also, samples were collected during the runs at selected time intervals and were analyzed as described below.

\subsection{Bacterial Sample Analysis}

The drop plate method was used to estimate the concentration of viable bacteria in the samples by enumerating the CFU grown on a LB agar plate (Herigstad et al. 2001). The samples taken from the bacterial suspension in the reactor were serially diluted down to $10^{-5}$ (with a factor of $10^{-1}$ ) of its initial concentration using the background electrolyte. 
Each dilution was thoroughly mixed, from which the $10 \mu \mathrm{L}$ drops were dispensed over the one-sixth of the surface of an agar plate which was then incubated at $37^{\circ} \mathrm{C}$ for $14 \mathrm{~h}$. After this time, CFU were counted and the average of the total count of CFU over 3 drops at the countable dilution was determined to calculate the initial concentration of bacteria. The viable cell density was initially $10^{7} \mathrm{CFU} / \mathrm{mL}$ in disinfection tests.

\subsection{Modes of Disinfection Action}

\subsubsection{Adhesion of Microbial Cells onto Electrodes}

Bacterial adhesion to the electrode surfaces and the culturability of the adhered cells was tested by performing control experiments with electrodes in place but without applying the current through the system. Furthermore, the viability of bacteria attached to the electrode surfaces was evaluated using BacLight Live/Dead assay (Live/Dead BacLight, Molecular Probes) which includes two DNA-binding stains: the green fluorescent stain, SYTO-9, and the red fluorescent stain, propidium iodide (PI). In this method, bacterial inactivation is measured based on the loss in membrane integrity of the cells (Boulos et al. 1999). Green fluorescing SYTO-9 is able to enter all cells, so is an indication of live cells, whereas red fluorescing PI enters only cells with damaged cytoplasmic membranes and is therefore an indication of non-viable cells (Asadishad et al. 2011, Boulos et al. 1999). After

disinfecting E. coli D21 suspension for $30 \mathrm{~min}$ (at a mild current density of $2 \mathrm{~mA} / \mathrm{cm}^{2}$ ), the working electrode was removed from the reactor and rinsed with the background electrolyte to remove unattached cells. Then, the surface of the electrode was stained with Live/Dead BacLight (Invitrogen) and imaged by fluorescence microscopy (IX-71, Olympus). The same procedure was repeated for E. coli $\mathrm{O} 157: \mathrm{H} 7$ and E. faecalis. 


\subsubsection{Influence of Solution Chemistry}

The role of electrochemically-produced hydroxyl radicals in inactivation of E. coli was investigated by adding methanol $(0.1 \mathrm{M})$, a well-known hydroxyl radical scavenger into the reactor medium (El-Morsi et al. 2000, Page et al. 2011). The influence of NOM, ubiquitously present in all freshwater systems (Cantwell et al. 2008), on electrochemical disinfection efficacy was also investigated using Suwannee River NOM (SR-NOM, 2R101N, IHSS) at concentrations of $2 \mathrm{mg} / \mathrm{L}$ and $10 \mathrm{mg} / \mathrm{L}$. To prepare the experimental suspension, SR-NOM was added to the electrolyte, well-mixed using a magnetic stir bar, and then the solution was filtered through a $0.45-\mu \mathrm{m}$ pore filter before adding bacteria. The influence of chloride concentration on electrochemical disinfection performance was investigated at a fixed current density of $2 \mathrm{~mA} / \mathrm{cm}^{2}$ by adding $\mathrm{NaCl}$ to the solution at different concentrations of $0,0.01,0.05$, and $0.1 \mathrm{M}$. The disinfecting ability of our electrochemical system through generation of oxidants other than chlorine was tested by conducting preliminary electrochemical experiments in chloride-free phosphate buffer solution. Moreover, the effect of $\mathrm{pH}$ on inactivation rate was studied. All experiments were run at least three times and after each experiment all the glassware and the reactor were cleaned with $10 \%$ bleach, washed twice with tap water and detergent, and then autoclaved at $121^{\circ} \mathrm{C}$ for $20 \mathrm{~min}$.

\subsubsection{Determination of Active Chlorine Production}

To evaluate the disinfecting role of oxidants produced in the presence of chloride in the solution during the electrochemical process, the amount of dissolved chlorine in the solution was determined as $\mathrm{mg} / \mathrm{L} \quad \mathrm{Cl}_{2}$ by $\mathrm{DPD}$ (N,N-diethyl-p-phenylendiamine) 
colorimetric method (Clesceri et al. 1989) from the magenta color produced as a result of the instantaneous reaction between active chlorine species and DPD indicator. Aliquots of $2 \mathrm{~mL}$ of the treated solution were collected in a cuvette containing $100 \mu \mathrm{L}$ of the phosphate buffer reagent for chlorine determination (RICCA, 5805-16) and $100 \mu \mathrm{L}$ DPD indicator (RICCA, 2655-16), and analyzed immediately by recording the absorption spectra in the range of 400-800 $\mathrm{nm}$ using a UV-Vis spectrophotometer. The concentration of free chlorine in samples was then calculated from the absorbance measured at $512 \mathrm{~nm}$ by using a calibration curve prepared previously with potassium permanganate solution as recommended (Clesceri et al. 1989), to a minimum detectable chlorine concentration of 50 $\mu \mathrm{g} / \mathrm{L}$.

\section{Results and Discussion}

\subsection{Role of Bacterial Adhesion onto Electrodes}

Control experiments performed with the electrodes in place but at zero current showed no observable decrease in $E$. coli D21 concentration in the reactor medium over a 60-min period (for an initial loading of $10^{7} \mathrm{CFU} / \mathrm{mL}$ ). This indicates that any observed decrease in bacterial load when the current is applied can be attributed to the electrochemical process. Microscope imaging (at 20X magnification) of the electrodes after $30 \mathrm{~min}$ of electrolysis at $2 \mathrm{~mA} / \mathrm{cm}^{2}$ showed no attached bacteria for E. coli $\mathrm{O} 157: \mathrm{H} 7$. For E. coli D21, most of the attached cells on the electrode were dead at the end of the test (as determined using the Live/Dead BacLight assay), whereas for E. faecalis, the number of attached bacteria was less than for $E$. coli D21 but most of the attached cells were live. The results show that the amount of cell adhesion to the electrodes and the extent of their 
inactivation were dependent on the type of bacteria with the Gram-positive E. faecalis being the most resistant and E. coli D21 the most susceptible to electrochemical disinfection.

\subsection{Influence of Current Density on Bacterial Inactivation}

Fig. 1 presents the influence of current density on changes in bacterial concentration during the electrochemical treatment of $E$. coli-contaminated solutions containing $0.1 \mathrm{M}$ $\mathrm{NaCl}(\mathrm{pH} 7.1 \pm 0.05)$. An increase in the current density from 0.2 to $1 \mathrm{~mA} / \mathrm{cm}^{2}$ resulted in more than $50 \%$ decrease in $\log _{10}$-bacterial concentration after 20 min. Further increase in the current density led to $100 \%$ inactivation ( 7.4-log reduction) of $10^{7} \mathrm{CFU} / \mathrm{mL}$ E. coli D21 within $5 \mathrm{~min}$ for $2 \mathrm{~mA} / \mathrm{cm}^{2}, 2 \mathrm{~min}$ for $4 \mathrm{~mA} / \mathrm{cm}^{2}, 1 \min$ for $6 \mathrm{~mA} / \mathrm{cm}^{2}$, and $1 \mathrm{~min}$ for $10 \mathrm{~mA} / \mathrm{cm}^{2}$ current density. The higher inactivation rates were achieved by increasing the applied current density, which is consistent with previous reports (Gómez-López et al. 2013, Schmalz et al. 2009). At a higher current density, more oxidizing species are generated at the anode surface to attack and kill microorganisms. However, increase in the current density from $6 \mathrm{~mA} / \mathrm{cm}^{2}$ to $10 \mathrm{~mA} / \mathrm{cm}^{2}$ did not raise the inactivation rate appreciably. This implication supports the statement reported elsewhere (Särkkä et al. 2008) that after reaching a threshold value for current density, the energy will be mainly used to produce oxygen and not oxidizing species.

Based on the results of the control experiment mentioned above, the decrease in the concentration of bacteria shown in Fig. 1 was due to the inactivation of E. coli cells, not due to the attachment of cells onto the electrode surface. Moreover, the fact that no notable decrease in bacterial concentration was observed at the current density of $0.2 \mathrm{~mA} / \mathrm{cm}^{2}$ implies that there is a threshold concentration for oxidants produced electrochemically, to 
cause bactericidal effects (Bensalah and Abdel-Wahab 2013a, b). At the lower threshold of current density, smaller number of oxidative species are produced, which is in agreement with the theory of electrochemistry. Given this and the fact that some oxidative species have a short life-time (e.g. OH-radicals), their concentration further away from the electrode surface rapidly drops, and thus, so does the bacteria inactivation rate.

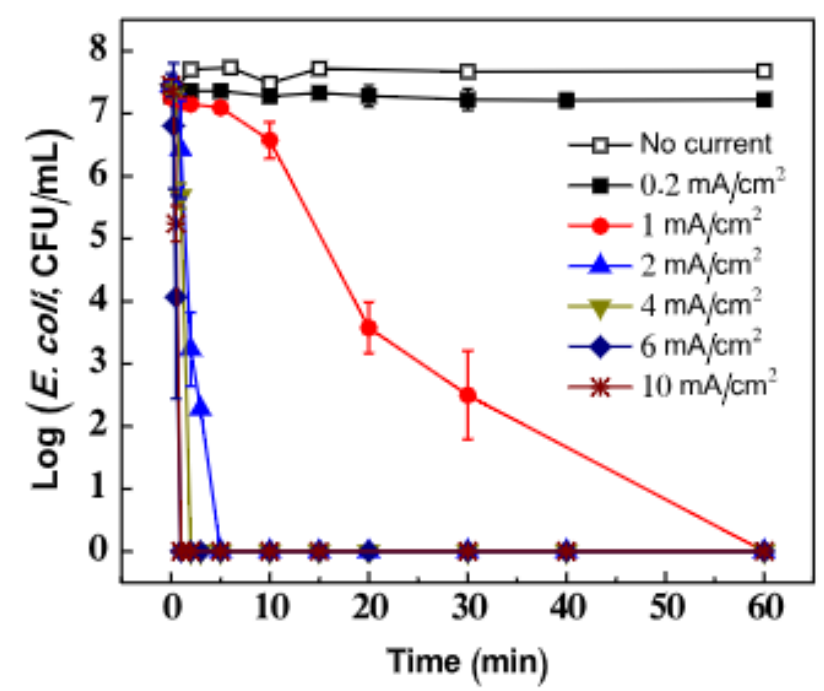

Fig. 1. Influence of current density on bacterial inactivation during electrochemical treatment of solutions containing initial concentration of $\sim 10^{7} \mathrm{CFU} / \mathrm{mL}$ E. coli D21 in $0.1 \mathrm{M} \mathrm{NaCl}+0.1 \mathrm{M}$ potassium phosphate buffer ( $\mathrm{pH} 7.1$ ). Results represent mean value $\pm \mathrm{SD}(\mathrm{n}=3$ ). 


\subsection{Effect of Interfering Species}

\subsubsection{Inhibitory Effect of Methanol on Bacterial Inactivation}

Practical application of disinfection systems is linked with their ability to maintain the disinfecting activity in the presence of radical scavengers such as bicarbonate, sulfate ions, halide ions, or alcohols (Billany et al. 1996, Grebel et al. 2010, Liao et al. 2001). Therefore, the possibility of their interference with disinfection activity must be considered for practical applications. We investigated the effect of methanol as a hydroxyl radical scavenger on the bacterial survival at two current densities of 2 and $4 \mathrm{~mA} / \mathrm{cm}^{2}$. Control experiments showed that addition of $0.1 \mathrm{M}$ methanol had no effect on $E$. coli inactivation, when no current was applied (solid squares) under the conditions used in this work (Fig. 2a). E. coli inactivation was significantly retarded by addition of methanol when the current was flowing through the cell, leading to $80 \%$ and $19 \%$ bacterial survival after 30 min at current densities of 2 and $4 \mathrm{~mA} / \mathrm{cm}^{2}$, respectively (compare the solid with open symbols in Fig. 2a). Since methanol is a known radical scavenger, thus reducing the potential formation of hydrogen peroxide, ozone and atomic oxygen (Eqs. (2-5)), this finding indicates that electrochemically-generated ROS play an essential role in the second stage inactivation of bacteria, assuming the first stage can be attributed to the direct

oxidation at the electrode surface (Jeong et al. 2007). The hole-scavenging effect of methanol could also negatively affect the formation of free chlorine and consequently other reactive chlorine species. 


\subsubsection{Inhibitory Effect of Natural Organic Matter (NOM) on Bacterial Inactivation}

Water supplies that require disinfection may contain varying loads of natural organic matter (NOM) that may impact treatment efficiency. Therefore, it is important to examine the effect of NOM on the efficacy of the electrochemical disinfection process. Fig. $2 \mathrm{~b}$ shows the removal of $E$. coli $\mathrm{D} 21$ in the absence and presence of 2 and $10 \mathrm{mg} / \mathrm{L}$ of SR-NOM as a function of time during the electrochemical treatment in $0.1 \mathrm{M} \mathrm{NaCl}+0.1$ M potassium phosphate buffer electrolyte. The contact time required to reach 100\% (7.4$\log$ ) bacterial inactivation increased from $5 \mathrm{~min}$ in the absence of SR-NOM to $15 \mathrm{~min}$ and $20 \mathrm{~min}$ in the presence of $2 \mathrm{mg} / \mathrm{L}$ and $10 \mathrm{mg} / \mathrm{L}$ SR-NOM, respectively. Thus, SR-NOM reduced the inactivation efficiency of the electrochemical process. Overall, the strong inhibitory effect of organic matter on bacterial inactivation can be attributed to a combination of several effects such as radical scavenging (Aeschbacher et al. 2012, Romera-Castillo and Jaffé 2015), inhibition of the catalytic process by faster adsorption onto the catalyst sites and occupying them, and competition between the organic compounds and the microorganisms for hydroxyl radicals (Gomes et al. 2009, Rodrigues et al. 2007). It has also been found that humic substances offer protection against solar (Gomes et al. 2009, Rodrigues et al. 2007) and UV (Cantwell et al. 2008, Muela et al. 2002) irradiation in photolytic or photocatalytic inactivation of bacteria (and also viruses (Templeton et al. 2006)) and lengthen the survival of microorganisms, mainly due to the formation of a thin coating on the surface of the cells presenting a blocking effect (Cantwell et al. 2008). 
Possible reactions between chlorine and NOM include (a) oxidation, (b) addition to unsaturated bonds, and (c) electrophilic substitution, leading to the production of chlorinated carbonaceous disinfection by-products (DBPs), such as trihalomethanes (THMs), haloacetic acids (HAAs) and haloacetonitriles (HANs) (Golea et al. 2017, Yee et al. 2006). The presence of organic matter may also lead to the decomposition of $\mathrm{HClO}$ via two possible chain reactions (Eqs. (9-12)) (Feng et al. 2007), thus consuming active chlorine species and reducing the disinfection efficacy:

$\bullet$ OH chain:

$$
\begin{aligned}
& \mathrm{HO}^{\bullet}+\mathrm{RH}(\mathrm{NOM}) \rightarrow \mathrm{R}^{\bullet}+\mathrm{H}_{2} \mathrm{O} \\
& \mathrm{R}^{\bullet}+\mathrm{HClO} \rightarrow \mathrm{RCl}+\mathrm{HO}^{\bullet}
\end{aligned}
$$

${ }^{\bullet} \mathrm{Cl}$ chain:

$$
\begin{aligned}
& \mathrm{Cl}^{\bullet}+\mathrm{RH}(\mathrm{NOM}) \rightarrow \mathrm{R}^{\bullet}+\mathrm{HCl} \\
& \mathrm{R}^{\bullet}+\mathrm{HClO} \rightarrow \mathrm{ROH}+\mathrm{Cl} l^{\bullet}
\end{aligned}
$$



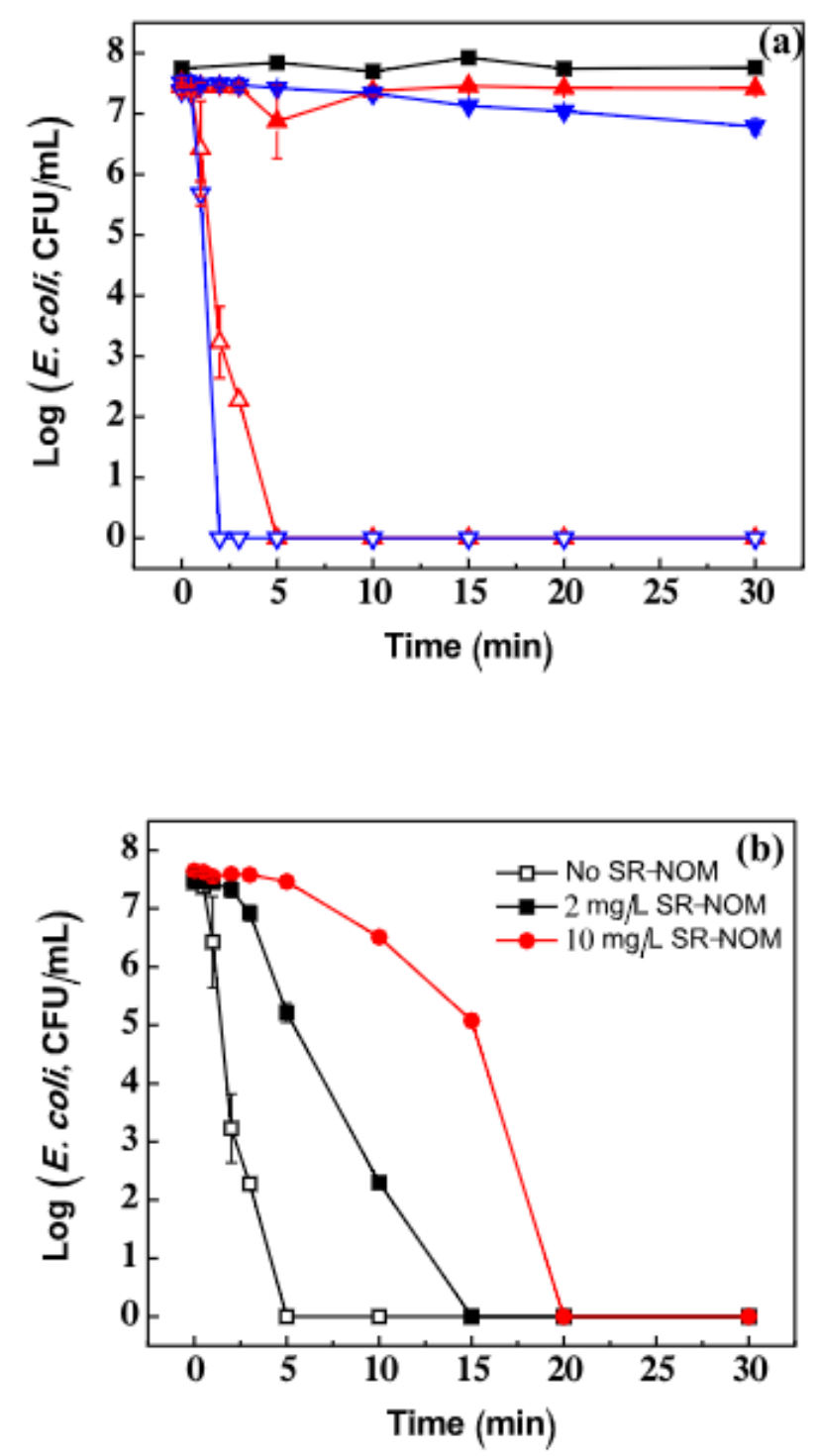

Fig. 2. Inhibitory effects of (a) a radical scavenger at zero current (a), $2 \mathrm{~mA} / \mathrm{cm}^{2}$ current density without adding methanol $(\Delta), 2 \mathrm{~mA} / \mathrm{cm}^{2}$ current density with $0.1 \mathrm{M}$ methanol $(\boldsymbol{\Delta}), 4 \mathrm{~mA} / \mathrm{cm}^{2}$ current density without adding methanol $(\nabla), 4 \mathrm{~mA} / \mathrm{cm}^{2}$ current density with $0.1 \mathrm{M}$ methanol ( $\boldsymbol{\nabla}$ ); and (b) SR-NOM at $2 \mathrm{~mA} / \mathrm{cm}^{2}$ current density, on changes in the number of E. coli D21 culturable cells in the reactor during the electrochemical treatment of $0.1 \mathrm{M} \mathrm{NaCl}+0.1 \mathrm{M}$ potassium phosphate buffer solution ( $\mathrm{pH} 7.1)$. Results represent mean value $\pm \mathrm{SD}(\mathrm{n}=3)$. 


\subsection{Role of Active Chlorine Oxidants}

\subsubsection{Influence of Current Density on Active Chlorine Production}

The concentration of active chlorine species (dissolved $\mathrm{Cl}_{2}, \mathrm{HOCl}$ and $\mathrm{ClO}^{-}$) in the electrolyte samples was determined using the DPD colorimetric method. It should be noted that, in addition to chlorine, other possible oxidants (e.g., $\mathrm{O}_{3}, \mathrm{H}_{2} \mathrm{O}_{2}, \mathrm{ClO}_{2}$ ) generated in electrochemical disinfection process can also react with DPD and contribute to the magenta color, and therefore the DPD test results may in fact represent the total oxidizing potential of electrochemically produced oxidants (Harp 2002, Schmalz et al. 2009). Fig. 3a shows the electrochemical generation of active chlorine at different constant current densities, obtained at fixed initial chloride concentration of $0.1 \mathrm{M}$ and $\mathrm{pH} 7.1 \pm 0.05$ in the absence of bacteria. As shown in Fig. 3a, no significant concentration of active chlorine was detected in experiments at the current density of $1 \mathrm{~mA} / \mathrm{cm}^{2}$. The chlorine production increased significantly from $\sim 0.5 \mathrm{mg} / \mathrm{L}$ up to $3.3 \mathrm{mg} / \mathrm{L}$ after $20 \mathrm{~min}$, as the current density was raised from $1 \mathrm{~mA} / \mathrm{cm}^{2}$ to $2 \mathrm{~mA} / \mathrm{cm}^{2}$, and it remained relatively constant with time. However, although further increase in current density to 4 and to $10 \mathrm{~mA} / \mathrm{cm}^{2}$ resulted in an increase in the maximum amount of chlorine produced (Fig. 3a), the amount of chlorine decreased after 20 and 15 minutes, respectively. Having a relatively high concentration of ions, the system is not expected to be in a mass transport controlling regime, but increasing the applied current to higher values could shift the process to become limited by mass transport conditions and/or chlorate $\left(\mathrm{ClO}_{3}^{-}\right)$production by possible side reactions occurring at the anode (Eq. (13)) or in the aqueous solution (Eq. (14)), as expressed below (Fraga et al. 2009): 


$$
\begin{aligned}
& 6 \mathrm{ClO}^{-}+3 \mathrm{H}_{2} \mathrm{O} \rightarrow 2 \mathrm{ClO}_{3}^{-}+6 \mathrm{H}^{+}+4 \mathrm{Cl}^{-}+1.5 \mathrm{O}_{2}+6 e^{-} \\
& 2 \mathrm{HClO}+\mathrm{ClO}^{-} \rightarrow \mathrm{ClO}_{3}^{-}+2 \mathrm{Cl}^{-}+2 \mathrm{H}^{+}
\end{aligned}
$$

However, due to the complexity of the method for determining the chlorate concentration, the measurements were not performed in this work.

\subsubsection{Effect of Chloride Concentration on Active Chlorine Production}

To determine the amount of active chlorine produced during the electrochemical treatment, the experiments were performed in the absence of bacteria. Fig. $3 b$ shows the

effect of initial chloride concentration on the electrochemical generation of active chlorine at $2 \mathrm{~mA} / \mathrm{cm}^{2}$ current density. As expected, chlorine formation increased with the amount of $\mathrm{NaCl}$ added, with the maximum value observed at $\mathrm{t}=15$ min increasing from $0.22 \mathrm{mg} / \mathrm{L}$ for $0.01 \mathrm{M} \mathrm{NaCl}$ to 1.02 and $3.18 \mathrm{mg} / \mathrm{L}$ for $0.05 \mathrm{M}$ and $0.1 \mathrm{M} \mathrm{NaCl}$, respectively. This observation that the significant production of active chlorine started at $0.1 \mathrm{M} \mathrm{NaCl}$, is in agreement with an earlier study regarding the requirement for a minimum chloride concentration for the formation of active chlorine leading to an effective inactivation of bacteria (Bergmann and Koparal 2005). However, the formation of free chlorine even at very low concentration of $\mathrm{NaCl}(0.01 \mathrm{M})$ was detected (Fig. 3b).

\subsubsection{Influence of pH on Active Chlorine Production}

The influence of $\mathrm{pH}$ on active chlorine production was investigated by comparing the electrochemical disinfection results obtained for solutions containing $0.1 \mathrm{M} \mathrm{NaCl}$ at $\mathrm{pH}$ 5.0 and $\mathrm{pH} 9.0$ conducted at $2 \mathrm{~mA} / \mathrm{cm}^{2}$ with results obtained at $\mathrm{pH} 7.1$. The amount of active chlorine produced during $60 \mathrm{~min}$ of electrolysis was measured at different time 
intervals, as shown in Fig. 3c. As can be seen, the free chlorine production decreased with increasing $\mathrm{pH}$, and the decrease was sharper going from $\mathrm{pH} 7.1$ to 9.0; the amount of active chlorine produced at $\mathrm{pH} 9$ was significantly lower than those measured at both $\mathrm{pH} 5.0$ and pH 7.1 (Student's t-test). However, the amount of generated chlorine measured at pH 5.0 and $\mathrm{pH} 7.1$ were not significantly different, except at $t=45 \mathrm{~min}$. The decrease in chlorine production at high $\mathrm{pH}$ values can be attributed to the preferential adsorption of $\mathrm{HO}^{-}$on the anode surface at basic conditions (Zanoni et al. 2004). Furthermore, at lower pH, more hypochlorous acid is produced (Eq. (7)), whereas at higher $\mathrm{pH}$ more hypochlorite ion is formed (Eq. (8)), which has lower oxidation potential than hypochlorous acid (Särkkä et al. 2008). Moreover, it is believed that increased acidity decreases the scavenging effect of potential radical scavengers (Lipczynska-Kochany et al. 1995). Thus, this system is expected to exhibit higher disinfection efficiency at neutral or acidic conditions. 

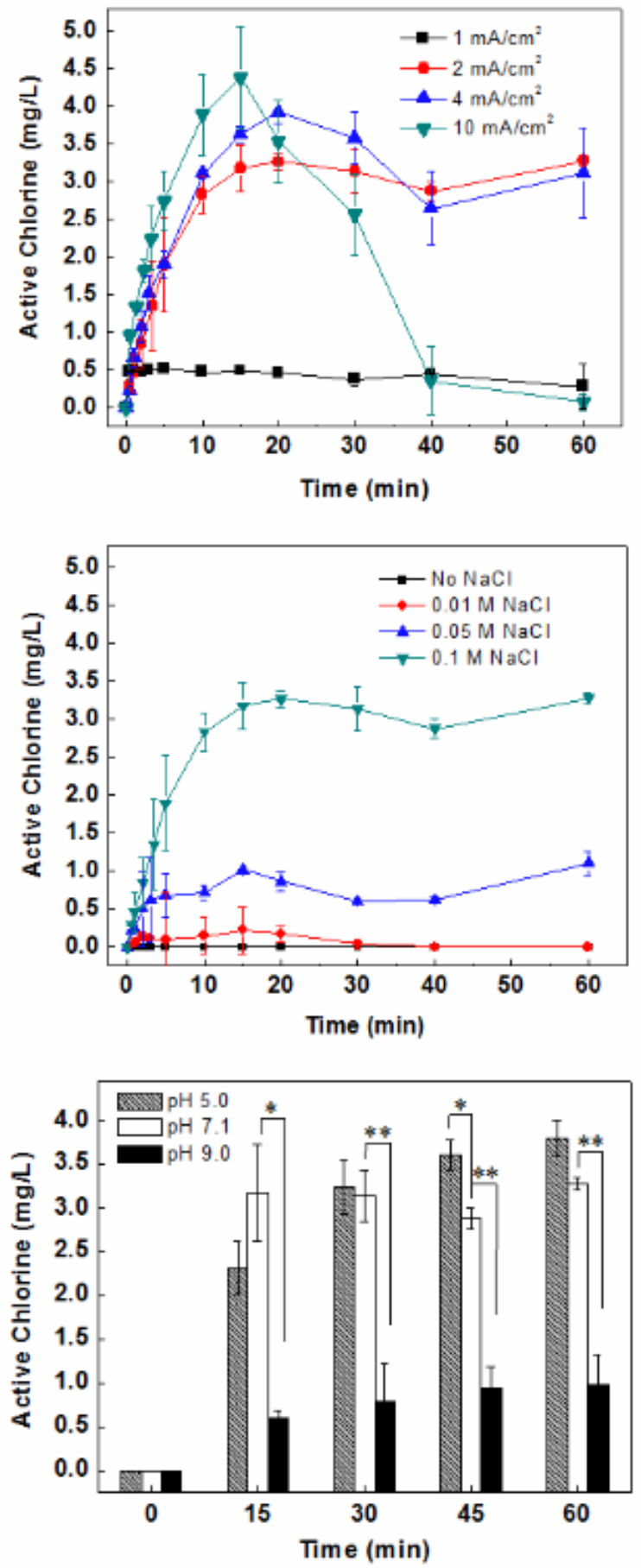

Fig. 3. Effects of (a) current density in $0.1 \mathrm{M} \mathrm{NaCl}(\mathrm{pH} \mathrm{7.1),} \mathrm{(b)} \mathrm{chloride} \mathrm{concentration} \mathrm{at} \mathrm{the}$ current density of $2 \mathrm{~mA} / \mathrm{cm}^{2}(\mathrm{pH} 7.1)$, and (c) solution $\mathrm{pH}$ at $0.1 \mathrm{M} \mathrm{NaCl}$ on active chlorine production during electrochemical water treatment in $0.1 \mathrm{M}$ potassium phosphate buffer. Results represent mean value $\pm \mathrm{SD}(\mathrm{n}=3){ }^{*} \mathrm{p} \leq 0.05 ; * \mathrm{p} \leq 0.01$. 


\subsection{Effect of Chloride Concentration on Bacterial Inactivation}

Fig. 4 presents the influence of initial chloride concentration on the electrochemical inactivation of $10^{7} \mathrm{CFU} / \mathrm{mL}$ E. coli $\mathrm{D} 21$ at a fixed current density of $2 \mathrm{~mA} / \mathrm{cm}^{2}$. The bactericidal efficiency of the electrochemical process was improved by increasing the concentration of $\mathrm{NaCl}$. For the experiment performed in the absence of $\mathrm{NaCl}$, complete bacterial inactivation was not achieved within 30 min of operation. Addition of $0.01 \mathrm{M}$ and $0.05 \mathrm{M} \mathrm{NaCl}$ exhibited similar effects on the bacterial inactivation rate and shortened the contact time required for $100 \%$ inactivation to $15 \mathrm{~min}$. At the increased chloride concentration of $0.1 \mathrm{M}, 100 \%$ disinfection was achieved in 4.5 min. Increasing $\mathrm{NaCl}$ concentration results in an enhanced production of ROS and, thus, faster bacterial inactivation.

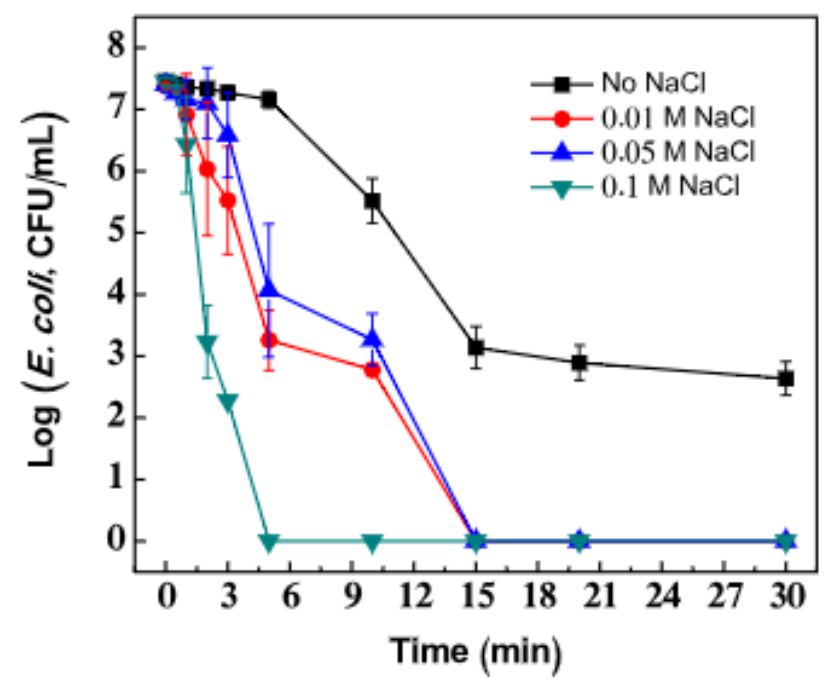

Fig. 4. Influence of $\mathrm{NaCl}$ concentration on the number of culturable cells in the reactor during the electrochemical treatment of $\sim 10^{7} \mathrm{CFU} / \mathrm{mL}$ E. coli D21 at current density $2 \mathrm{~mA} / \mathrm{cm}^{2}$ and in $0.1 \mathrm{M}$ potassium phosphate buffer $(\mathrm{pH} 7.1)$. Results represent mean value $\pm \mathrm{SD}(\mathrm{n}=3)$. 


\subsection{Effect of Initial Bacterial Load and Strain Type}

The influence of initial bacterial cell density on the number of culturable cells in the reactor for E. coli D21 is shown in Fig. 5. As can be seen, the required contact time for $100 \%$ bacterial inactivation increased with bacterial load. At the current density of 0.2 $\mathrm{mA} / \mathrm{cm}^{2}$, the percentage of surviving cells of $E$. coli at an initial load of $10^{5}$ and $10^{7}$ $\mathrm{CFU} / \mathrm{mL}$ was found to be $30 \%$ and $88 \%$, respectively, within 5 min of electrolysis. A similar trend was observed at the applied current density of $1 \mathrm{~mA} / \mathrm{cm}^{2}$. This finding that the percentage of surviving cells increased with the initial bacterial density is in agreement with previous reports (Bekbölet 1997, Jeong et al. 2007). Besides the lower oxidants/bacteria ratio, higher coverage of the electrode surface by bacterial cells due to electrostatic attraction between positively charged anode surface and negatively charged E. coli cells, in solutions with higher bacterial loads may cause a blocking effect at the electrode surface retarding the electron transfer to the ions and thus lower production of oxidative species. 


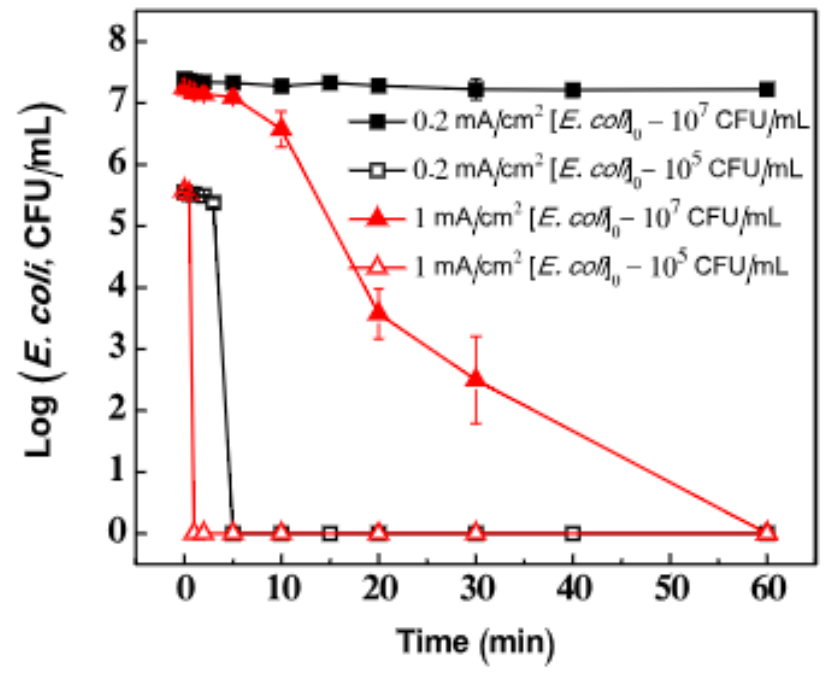

Fig. 5. Effect of initial bacterial load on the percentage of culturable E. coli D21 cells during electrochemical treatment of $0.1 \mathrm{M} \mathrm{NaCl}+0.1 \mathrm{M}$ potassium phosphate buffer solution ( $\mathrm{pH} 7.1)$. Results represent mean value $\pm \mathrm{SD}(\mathrm{n}=3)$.

Fig. 6 shows the decay of the number of culturable cells in the reactor with time during the electrochemical treatment of aqueous solutions containing $0.1 \mathrm{M} \mathrm{NaCl}$ contaminated with different model bacteria; namely, E. coli $\mathrm{D} 21$, E. coli $\mathrm{O} 157: \mathrm{H} 7$ and E. faecalis. As can be seen, total bacterial inactivation was achieved for both E. coli strains. The electrochemical process was less effective against the Gram+ bacterium tested, however, a significant number of cells were still inactivated. 


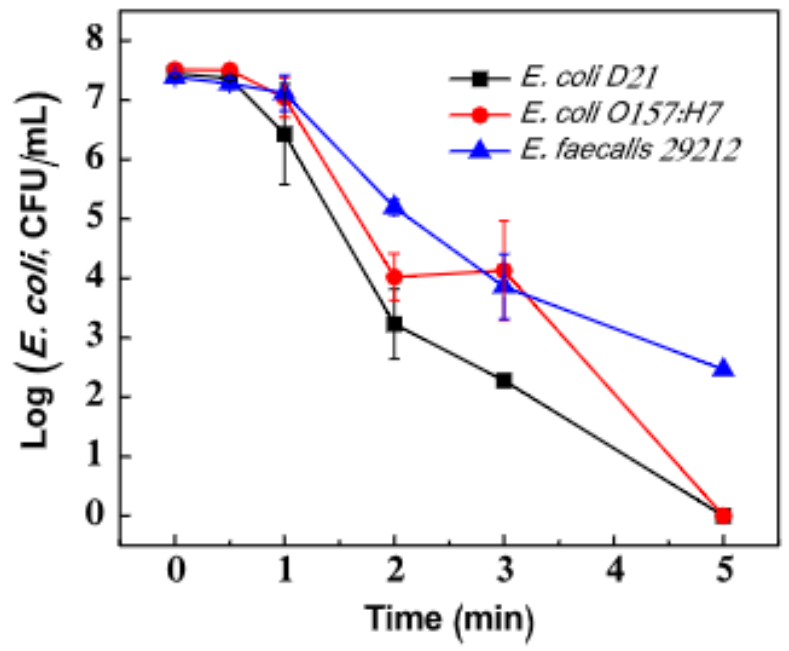

Fig. 6. Changes in the number of culturable cells with time for different bacterial strains during the electrochemical treatment of $0.1 \mathrm{M} \mathrm{NaCl}+0.1 \mathrm{M}$ potassium phosphate buffer solution ( $\mathrm{pH}$ 7.1) at current density of $2 \mathrm{~mA} / \mathrm{cm}^{2}$. Results represent mean value $\pm S D(n=4)$.

\subsection{Energy Consumption During the Electrochemical Disinfection Process}

Although higher current densities result in higher microbial inactivation, they are associated with greater energy consumption. To understand the cost effectiveness of the process, the performance of electrochemical disinfection was evaluated in terms of energy efficiency. The process intrinsic energy (considering only the electrical energy) required to achieve a $3.5-\log$ reduction as well as complete inactivation (7.4-log reduction) of $10^{7}$ $\mathrm{CFU} / \mathrm{mL}$ E. coli $\mathrm{D} 21$ was calculated based on the required contact time, current density, and the resulting cell voltage (Table 1). The maximum increase in the temperature of the reactor medium was less than $1^{\circ} \mathrm{C}$ in all operations. By increasing the current density from $6 \mathrm{~mA} / \mathrm{cm}^{2}$ to $10 \mathrm{~mA} / \mathrm{cm}^{2}$, the treatment time required for complete removal of bacteria did not change, but the energy consumption increased by $100 \%$. This result confirms the statement above that after a certain threshold value for current density, the additional energy input will mostly generate oxygen and not oxidative species. Thus, the current 
density of $6 \mathrm{~mA} / \mathrm{cm}^{2}$ was the most efficient in terms of energy consumption to achieve an equal $E$. coli inactivation, corresponding to an energy input of $48.18 \mathrm{Wh} / \mathrm{m}^{3}$ for $100 \%$ bacterial inactivation. This estimated value is considerably lower than that obtained by Lacasa et al. (Lacasa et al. 2013) $\left(88 \mathrm{Wh} / \mathrm{m}^{3}\right)$ and Heim et al. (Heim et al. 2015) (250 $\mathrm{Wh} / \mathrm{m}^{3}$ ) required to completely inactivate $10^{6}-10^{7} \mathrm{CFU} / \mathrm{mL}$ and $10^{7}-10^{8} \mathrm{CFU} / \mathrm{mL}$ E. coli in water containing $30 \mathrm{~g} / \mathrm{L}(\sim 0.5 \mathrm{M})$ and $20 \mathrm{~g} / \mathrm{L}(\sim 0.35 \mathrm{M}) \mathrm{NaCl}$ using BDD anodes, respectively. Also, these values are on the same order of magnitude as values reported in the literature for inactivation of $10^{7} \mathrm{CFU} / \mathrm{mL}$ E. coli in $\mathrm{Na}_{2} \mathrm{SO}_{4}$ electrolyte using BDD anode ( $\mathrm{Li}$ et al. 2010). The calculated values for energy consumption listed in Table 1 represent promising results when compared to the $7 \mathrm{~kJ} / \mathrm{L}\left(\sim 1944 \mathrm{Wh} / \mathrm{m}^{3}\right)$ UV energy used to reach a final concentration of $10 \mathrm{CFU} / \mathrm{mL}$ from an initial E. coli load of $4.25 \times 10^{5}$ CFU/mL by photolysis, as reported by Gomes et al. (Gomes et al. 2009), and $4.2 \mathrm{~kJ} / \mathrm{L}$ ( $1167 \mathrm{Wh} / \mathrm{m}^{3}$ ) UV energy required to reduce the initial E. coli concentration of $10^{7}$ to 90 CFU/mL by solar photocatalysis using $\mathrm{TiO}_{2}$, as shown by Sichel et al. (Sichel et al. 2007). 


\section{Table 1}

Calculated process intrinsic electrical energy consumption for 3.5-log removal and complete inactivation (7.4-log reduction) of $E$. coli D21 with the initial concentration of $10^{7} \mathrm{CFU} / \mathrm{mL}$ during the electrochemical treatment of $0.1 \mathrm{M} \mathrm{NaCl}+0.1 \mathrm{M}$ potassium phosphate buffer solution $(\mathrm{pH} 7.1)$. Data represent mean value $\pm \mathrm{SD}(\mathrm{n}=3)$.

\begin{tabular}{|c|c|c|c|c|c|c|c|c|c|c|}
\hline \multirow{3}{*}{$\begin{array}{c}\begin{array}{c}\text { Current } \\
\text { density }\end{array} \\
\left(\mathrm{mA} / \mathrm{cm}^{2)}\right.\end{array}$} & \multicolumn{5}{|c|}{ 3.5-log reduction } & \multicolumn{5}{|c|}{ 7.4-log reduction (complete inactivation) } \\
\hline & \multirow{2}{*}{$\begin{array}{c}\begin{array}{c}\text { Voltag } \\
\mathrm{e}\end{array} \\
(\mathrm{V}) \\
1.1\end{array}$} & \multirow{2}{*}{$\begin{array}{c}\text { Time } \\
(\min \\
)\end{array}$} & \multicolumn{3}{|c|}{$\begin{array}{c}E_{3.5-\log } \\
\left(\mathrm{Wh} / \mathrm{m}^{3}\right)\end{array}$} & \multirow{2}{*}{$\begin{array}{c}\begin{array}{c}\text { Voltag } \\
\mathrm{e}\end{array} \\
(\mathrm{V}) \\
1.1\end{array}$} & \multirow{2}{*}{$\begin{array}{c}\text { Time } \\
(\min \\
)\end{array}$} & \multicolumn{3}{|c|}{$\begin{array}{c}E_{7.4 \mathrm{log}} \\
\left(\mathrm{Wh} / \mathrm{m}^{3}\right)\end{array}$} \\
\hline & & & & & & & & & & \\
\hline 1 & 3.8 & 20 & $\begin{array}{c}115.7 \\
6\end{array}$ & \pm & $\begin{array}{c}5.8 \\
1\end{array}$ & 3.9 & 60 & $\begin{array}{c}355.4 \\
5\end{array}$ & \pm & $\begin{array}{c}21.6 \\
0\end{array}$ \\
\hline 2 & 4.1 & 2 & 24.85 & \pm & $\begin{array}{c}1.2 \\
5\end{array}$ & 4.2 & 5 & 63.64 & \pm & 4.33 \\
\hline 4 & 4.4 & 2 & 53.33 & \pm & $\begin{array}{c}2.1 \\
5\end{array}$ & 4.4 & 2 & 53.33 & \pm & 2.15 \\
\hline 6 & 5.3 & 1 & 48.18 & \pm & $\begin{array}{c}3.2 \\
2\end{array}$ & 5.3 & 1 & 48.18 & \pm & 3.21 \\
\hline 10 & 6.6 & 1 & 99.24 & \pm & $\begin{array}{c}2.5 \\
7\end{array}$ & 6.6 & 1 & 99.24 & \pm & 2.57 \\
\hline
\end{tabular}




\section{Conclusions}

This study demonstrates the strong bactericidal activity of Sb-doped $\mathrm{Sn}_{80 \%}-\mathrm{W}_{20 \%}$ oxide anodes, which increased with increasing current density and $\mathrm{NaCl}$ concentration. This can be explained by the advancing role of mediated oxidation processes carried out by the electrogenerated oxidants including ROS and RCS in the inactivation of bacteria. It was found that the electrochemically-generated ROS (e.g. hydroxyl radicals, hydrogen peroxide, ozone) and $\mathrm{RCS}\left(\right.$ e.g. $\mathrm{Cl}_{2}, \mathrm{HOCl}, \mathrm{ClO}^{-}$) were mainly responsible for inactivation of bacteria at high and low current densities, respectively. It was also found that the presence of NOM and other radical scavengers such as methanol adversely affect $E$. coli inactivation by electrochemical treatment. Increasing the $\mathrm{pH}$ of the solution also resulted in a lower bacterial inactivation rate. Moreover, the results showed that the treatment was effective against model Gram-negative and Gram-positive bacteria. The highest efficiency for total electrochemical disinfection of $E$. coli D21 at an initial load of $10^{7} \mathrm{CFU} / \mathrm{mL}$ was obtained at $6 \mathrm{~mA} / \mathrm{cm}^{2}$ current density with $0.1 \mathrm{M} \mathrm{NaCl}$ at $\mathrm{pH} 7.1$ with a power consumption of $0.048 \mathrm{kWh} / \mathrm{m}^{3}$. The study concludes that $\mathrm{Sb}$-doped $\mathrm{Sn}_{80 \%}-\mathrm{W}_{20 \%}$-oxide anodes are effective electrocatalysts for production of powerful oxidants in aqueous solutions towards the efficient disinfection of bacteria by electrochemical treatments. The potential production of disinfection by-products such as trihalomethanes and haloacetic acids was not monitored in this preliminary proof-of-concept work and should be considered for practical applications. 


\section{Acknowledgements}

The authors acknowledge the Natural Sciences and Engineering Research Council of Canada (NSERC) for funding awarded to S.O. and N.T, the Canada Research Chairs Program and a McGill Engineering Doctoral Award to S.G. 


\section{References}

A. Lawton, L. and K. J. Robertson, P. (1999) Physico-chemical treatment methods for the removal of microcystins (cyanobacterial hepatotoxins) from potable waters. Chemical Society Reviews 28(4), 217224.

Aeschbacher, M., Graf, C., Schwarzenbach, R.P. and Sander, M. (2012) Antioxidant Properties of Humic Substances. Environmental Science \& Technology 46(9), 4916-4925.

Anglada, Á., Urtiaga, A. and Ortiz, I. (2009) Contributions of electrochemical oxidation to wastewater treatment: fundamentals and review of applications. Journal of Chemical Technology \& Biotechnology 84(12), 1747-1755.

Asadishad, B., Ghoshal, S. and Tufenkji, N. (2011) Method for the Direct Observation and Quantification of Survival of Bacteria Attached to Negatively or Positively Charged Surfaces in an Aqueous Medium. Environmental Science \& Technology 45(19), 8345-8351.

Bekbölet, M. (1997) Photocatalytic bactericidal activity of $\mathrm{TiO}_{2}$ in aqueous suspensions of $E$. Coli. Water Science and Technology 35(11-12), 95-100.

Bensalah, N. and Abdel-Wahab, A. (2013a) Electrochemical Inactivation of P. Aeruginosa, A. hydrophila, L. pneumophila using Boron Doped Diamond Anodes, p. 9.

Bensalah, N. and Abdel-Wahab, A. (2013b) Electrochemical Inactivation of P. Aeruginosa, A. hydrophila, L. pneumophila using Boron Doped Diamond Anodes. Journal of Advanced Oxidation Technologies 16(1), 9-15.

Bergmann, H., Koparal, A.T., Koparal, A.S. and Ehrig, F. (2008) The influence of products and byproducts obtained by drinking water electrolysis on microorganisms. Microchemical Journal 89(2), 98107.

Bergmann, M.E.H. and Koparal, A.S. (2005) Studies on electrochemical disinfectant production using anodes containing $\mathrm{RuO}_{2}$. Journal of Applied Electrochemistry 35(12), 1321-1329.

Billany, M.R., Khatib, K., Gordon, M. and Sugden, J.K. (1996) Alcohols and ethanolamines as hydroxyl radical scavengers. International Journal of Pharmaceutics 137(2), 143-147.

Boulos, L., Prévost, M., Barbeau, B., Coallier, J. and Desjardins, R. (1999) LIVE/DEAD ${ }^{\circledR}$ BacLight $^{\mathrm{TM}}$ : application of a new rapid staining method for direct enumeration of viable and total bacteria in drinking water. Journal of Microbiological Methods 37(1), 77-86.

Butterfield, I.M., Christensen, P.A., Curtis, T.P. and Gunlazuardi, J. (1997) Water disinfection using an immobilised titanium dioxide film in a photochemical reactor with electric field enhancement. Water Research 31(3), 675-677.

Cantwell, R.E., Hofmann, R. and Templeton, M.R. (2008) Interactions between humic matter and bacteria when disinfecting water with UV light. Journal of Applied Microbiology 105(1), 25-35.

Clesceri, L.S., Greenberg, A.E. and Trussell, R.R. (1989) Standard methods for the examination of water and wastewater, APHA-AWWA-WPCF, Washington, DC.

Diao, H.F., Li, X.Y., Gu, J.D., Shi, H.C. and Xie, Z.M. (2004) Electron microscopic investigation of the bactericidal action of electrochemical disinfection in comparison with chlorination, ozonation and Fenton reaction. Process Biochemistry 39(11), 1421-1426.

Drees, K.P., Abbaszadegan, M. and Maier, R.M. (2003) Comparative electrochemical inactivation of bacteria and bacteriophage. Water Research 37(10), 2291-2300.

Drogui, P., Elmaleh, S., Rumeau, M., Bernard, C. and Rambaud, A. (2001) Oxidising and disinfecting by hydrogen peroxide produced in a two-electrode cell. Water Research 35(13), 3235-3241.

El-Morsi, T.M., Budakowski, W.R., Abd-El-Aziz, A.S. and Friesen, K.J. (2000) Photocatalytic Degradation of 1,10-Dichlorodecane in Aqueous Suspensions of $\mathrm{TiO}_{2}$ : A Reaction of Adsorbed 
Chlorinated Alkane with Surface Hydroxyl Radicals. Environmental Science \& Technology 34(6), 1018-1022.

Fang, Q., Shang, C. and Chen, G. (2006) MS2 Inactivation by Chloride-Assisted Electrochemical Disinfection. Journal of Environmental Engineering 132(1), 13-22.

Feng, C., Suzuki, K., Zhao, S., Sugiura, N., Shimada, S. and Maekawa, T. (2004) Water disinfection by electrochemical treatment. Bioresource Technology 94(1), 21-25.

Feng, Y., Smith, D.W. and Bolton, J.R. (2007) Photolysis of aqueous free chlorine species ( $\mathrm{HOCl}$ and OCl-) with $254 \mathrm{~nm}$ ultraviolet light. Journal of Environmental Engineering and Science 6(3), 277284.

Feng, Y., Yang, L., Liu, J. and Logan, B.E. (2016) Electrochemical technologies for wastewater treatment and resource reclamation. Environmental Science: Water Research \& Technology 2(5), 800831.

Flemming, H.-C. (2002) Biofouling in water systems - cases, causes and countermeasures. Applied Microbiology and Biotechnology 59(6), 629-640.

Fraga, L.E., Anderson, M.A., Beatriz, M.L.P.M.A., Paschoal, F.M.M., Romão, L.P. and Zanoni, M.V.B. (2009) Evaluation of the photoelectrocatalytic method for oxidizing chloride and simultaneous removal of microcystin toxins in surface waters. Electrochimica Acta 54(7), 2069-2076.

Ghasemian, S., Nasuhoglu, D., Omanovic, S. and Yargeau, V. (2017) Photoelectrocatalytic degradation of pharmaceutical carbamazepine using Sb-doped Sn80\%-W20\%-oxide electrodes. Separation and Purification Technology 188, 52-59.

Ghasemian, S. and Omanovic, S. (2017) Fabrication and characterization of photoelectrochemicallyactive Sb-doped Snx-W(100-x)\%-oxide anodes: Towards the removal of organic pollutants from wastewater. Applied Surface Science 416, 318-328.

Ghernaout, D., Badis, A., Kellil, A. and Ghernaout, B. (2008) Application of electrocoagulation in Escherichia coli culture and two surface waters. Desalination 219(1), 118-125.

Golea, D.M., Upton, A., Jarvis, P., Moore, G., Sutherland, S., Parsons, S.A. and Judd, S.J. (2017) THM and HAA formation from NOM in raw and treated surface waters. Water Research 112, 226235.

Gomes, A.I., Santos, J.C., Vilar, V.J.P. and Boaventura, R.A.R. (2009) Inactivation of Bacteria E. coli and photodegradation of humic acids using natural sunlight. Applied Catalysis B: Environmental 88(3-4), 283-291.

Gómez-López, V.M., Gobet, J., Selma, M.V., Gil, M.I. and Allende, A. (2013) Operating conditions for the electrolytic disinfection of process wash water from the fresh-cut industry contaminated with E. coli O157:H7. Food Control 29(1), 42-48.

Grahl, T. and Märkl, H. (1996) Killing of microorganisms by pulsed electric fields. Applied Microbiology and Biotechnology 45(1), 148-157.

Grebel, J.E., Pignatello, J.J. and Mitch, W.A. (2010) Effect of Halide Ions and Carbonates on Organic Contaminant Degradation by Hydroxyl Radical-Based Advanced Oxidation Processes in Saline Waters. Environmental Science \& Technology 44(17), 6822-6828.

Gusmão, I.C.C.P., Moraes, P.B. and Bidoia, E.D. (2010) Studies on the electrochemical disinfection of water containing Escherichia coli using a Dimensionally Stable Anode. Brazilian Archives of Biology and Technology 53, 1235-1244.

Harp, D.L. (2002) Current Technology of Chlorine Analysis for Water and Wastewater, HACH Company. 
Harper, J.C., Christensen, P.A., Egerton, T.A., Curtis, T.P. and Gunlazuardi, J. (2001) Effect of catalyst type on the kinetics of the photoelectrochemical disinfection of water inoculated with $E$. coli. Journal of Applied Electrochemistry 31(6), 623-628.

Heim, C., Ureña de Vivanco, M., Rajab, M., Müller, E., Letzel, T. and Helmreich, B. (2015) Rapid inactivation of waterborne bacteria using boron-doped diamond electrodes. International Journal of Environmental Science and Technology 12(10), 3061-3070.

Herigstad, B., Hamilton, M. and Heersink, J. (2001) How to optimize the drop plate method for enumerating bacteria. Journal of Microbiological Methods 44(2), 121-129.

Jeong, J., Kim, J.Y., Cho, M., Choi, W. and Yoon, J. (2007) Inactivation of Escherichia coli in the electrochemical disinfection process using a Pt anode. Chemosphere 67(4), 652-659.

Jeong, J., Kim, J.Y. and Yoon, J. (2006) The Role of Reactive Oxygen Species in the Electrochemical Inactivation of Microorganisms. Environmental Science \& Technology 40(19), 6117-6122.

Kraft, A. (2008) Electrochemical Water Disinfection: A Short Review. Platinum Metals Review 52(3), 177-185.

Kraft, A., Stadelmann, M., Blaschke, M., Kreysig, D., Sandt, B., Schröder, F. and Rennau, J. (1999) Electrochemical water disinfection Part I: Hypochlorite production from very dilute chloride solutions. Journal of Applied Electrochemistry 29(7), 859-866.

Lacasa, E., Tsolaki, E., Sbokou, Z., Rodrigo, M.A., Mantzavinos, D. and Diamadopoulos, E. (2013) Electrochemical disinfection of simulated ballast water on conductive diamond electrodes. Chemical Engineering Journal 223, 516-523.

Li, H., Zhu, X. and Ni, J. (2010) Inactivation of Escherichia coli in Na2SO4 electrolyte using borondoped diamond anode. Electrochimica Acta 56(1), 448-453.

Liang, W., Qu, J., Chen, L., Liu, H. and Lei, P. (2005) Inactivation of Microcystis aeruginosa by Continuous Electrochemical Cycling Process in Tube Using $\mathrm{Ti} / \mathrm{RuO}_{2}$ Electrodes. Environmental Science \& Technology 39(12), 4633-4639.

Liao, C.-H., Kang, S.-F. and Wu, F.-A. (2001) Hydroxyl radical scavenging role of chloride and bicarbonate ions in the $\mathrm{H}_{2} \mathrm{O}_{2} / \mathrm{UV}$ process. Chemosphere 44(5), 1193-1200.

Lipczynska-Kochany, E., Sprah, G. and Harms, S. (1995) Influence of some groundwater and surface waters constituents on the degradation of 4-chlorophenol by the Fenton reaction. Chemosphere 30(1), $9-20$.

Long, Y., Ni, J. and Wang, Z. (2015) Subcellular mechanism of Escherichia coli inactivation during electrochemical disinfection with boron-doped diamond anode: A comparative study of three electrolytes. Water Research 84, 198-206.

López-Gálvez, F., Posada-Izquierdo, G.D., Selma, M.V., Pérez-Rodríguez, F., Gobet, J., Gil, M.I. and Allende, A. (2012) Electrochemical disinfection: An efficient treatment to inactivate Escherichia coli O157:H7 in process wash water containing organic matter. Food Microbiology 30(1), 146-156.

Martínez-Huitle, C.A. and Brillas, E. (2008) Electrochemical Alternatives for Drinking Water Disinfection. Angewandte Chemie International Edition 47(11), 1998-2005.

Mascia, M., Vacca, A. and Palmas, S. (2013) Electrochemical treatment as a pre-oxidative step for algae removal using Chlorella vulgaris as a model organism and BDD anodes. Chemical Engineering Journal 219, 512-519.

Matsunaga, T., Nakasono, S., Takamuku, T., Burgess, J.G., Nakamura, N. and Sode, K. (1992) Disinfection of drinking water by using a novel electrochemical reactor employing carbon-cloth electrodes. Applied and Environmental Microbiology 58(2), 686-689.

Matsunaga, T., Okochi, M., Takahashi, M., Nakayama, T., Wake, H. and Nakamura, N. (2000) TiN electrode reactor for disinfection of drinking water. Water Research 34(12), 3117-3122. 
Mitch, W.A., Sharp, J.O., Trussell, R.R., Valentine, R.L., Alvarez-Cohen, L. and Sedlak, D.L. (2003) N-Nitrosodimethylamine (NDMA) as a Drinking Water Contaminant: A Review. Environmental Engineering Science 20(5), 389-404.

Muela, A., García-Bringas, J.M., Seco, C., Arana, I. and Barcina, I. (2002) Participation of Oxygen and Role of Exogenous and Endogenous Sensitizers in the Photoinactivation of Escherichia coli by Photosynthetically Active Radiation, UV-A and UV-B. Microbial Ecology 44(4), 354-364.

Nanayakkara, K.G.N. (2010) Ballast WaterTreatment Using Electrochemical Disinfection Technology. Ph.D. Thesis, National University of Singapore.

Page, S.E., Arnold, W.A. and McNeill, K. (2011) Assessing the Contribution of Free Hydroxyl Radical in Organic Matter-Sensitized Photohydroxylation Reactions. Environmental Science \& Technology 45(7), 2818-2825.

Palmas, S., Polcaro, A.M., Vacca, A., Mascia, M. and Ferrara, F. (2007) Characterization of boron doped diamond during oxidation processes: Relationship between electronic structure and electrochemical activity. Journal of Applied Electrochemistry 37(1), 63-70.

Panizza, M. and Cerisola, G. (2005) Application of diamond electrodes to electrochemical processes. Electrochimica Acta 51(2), 191-199.

Patermarakis, G. and Fountoukidis, E. (1990) Disinfection of water by electrochemical treatment. Water Research 24(12), 1491-1496.

Rahmawati, F., Kusumaningsih, T., Hapsari, A.M. and Hastuti, A. (2010) Ag and Cu loaded on $\mathrm{TiO}_{2} /$ graphite as a catalyst for Escherichia coli-contaminated water disinfection. Chemical Papers 64(5), 557-565.

Rajeshwar, K. and Ibanez, J.G. (1997) Environmental electrochemistry : fundamentals and applications in pollution abatement, Academic Press, San Diego.

Rodrigues, C.P., Ziolli, R.L. and Guimarães, J.R. (2007) Inactivation of Escherichia coli in water by $\mathrm{TiO}_{2}$-assisted disinfection using solar light. Journal of the Brazilian Chemical Society 18, 126-134.

Romera-Castillo, C. and Jaffé, R. (2015) Free radical scavenging (antioxidant activity) of natural dissolved organic matter. Marine Chemistry 177, Part 4, 668-676.

Särkkä, H., Vepsäläinen, M., Pulliainen, M. and Sillanpää, M. (2008) Electrochemical inactivation of paper mill bacteria with mixed metal oxide electrode. Journal of Hazardous Materials 156(1-3), 208213.

Schmalz, V., Dittmar, T., Haaken, D. and Worch, E. (2009) Electrochemical disinfection of biologically treated wastewater from small treatment systems by using boron-doped diamond (BDD) electrodes--contribution for direct reuse of domestic wastewater. Water Research 43(20), 5260-5266. Sichel, C., Blanco, J., Malato, S. and Fernández-Ibáñez, P. (2007) Effects of experimental conditions on E. coli survival during solar photocatalytic water disinfection. Journal of Photochemistry and Photobiology A: Chemistry 189(2-3), 239-246.

Szewzyk, U., Szewzyk, R., Manz, W. and Schleifer, K.-H. (2000) Microbiological Safety of Drinking Water. Annual Review of Microbiology 54(1), 81-127.

Tanaka, T., Shimoda, M., Shionoiri, N., Hosokawa, M., Taguchi, T., Wake, H. and Matsunaga, T. (2013) Electrochemical disinfection of fish pathogens in seawater without the production of a lethal concentration of chlorine using a flow reactor. Journal of Bioscience and Bioengineering 116(4), 480484.

Templeton, M.R., Hofmann, R. and Andrews, R.C. (2006) UV inactivation of humic-coated bacteriophages MS2 and T4 in water. Journal of Environmental Engineering and Science 5(6), 537543. 
Trussell, R.R. (1998) Overview of disinfectant residuals in drinking water distribution systems. Water Suply 16(3-4), 1-15.

Watts, R.J., Finn, D.D., Wyeth, M.S. and Teel, A.L. (2008) Performance Comparison of Tin Oxide Anodes to Commercially Available Dimensionally Stable Anodes. Water Environment Research 80(6), 490-496.

Yee, L.F., Abdullah, M.P., Ata, S. and Ishak, B. (2006) Dissolved Organic matter and Its Impact on The Chlorine Demand of The Treated Water. The Malaysian Journal of Analytical Sciences 10, 243 250.

Zanoni, M.V.B., Sene, J.J., Selcuk, H. and Anderson, M.A. (2004) Photoelectrocatalytic Production of Active Chlorine on Nanocrystalline Titanium Dioxide Thin-Film Electrodes. Environmental Science \& Technology 38(11), 3203-3208. 